Board of Governors of the Federal Reserve System

International Finance Discussion Papers

Number 522

September 1995

EXCESS RETURNS AND RISK AT THE LONG END OF

THE TREASURY MARKET: AN EGARCH-M APPROACH

Allan D. Brunner

David P. Simon

NOTE: International Finance Discussion Papers are preliminary materials circulated to stimulate discussion and critical comment. References in publications to International Finance Discussion Papers (other than an acknowledgement that the writer had access to unpublished material) should be cleared with the author or authors. 


\begin{abstract}
$\underline{\text { Abstract }}$
This paper models weekly excess returns of 10-year Treasury notes and long-term Treasury bonds from 1968 through 1993 using an exponential generalized autoregressive conditional heteroskedasticity in mean (EGARCH-M) approach. The results indicate the presence of conditional heteroskedasticity and a strong tendency for the ex-ante volatility of excess returns to increase more following negative excess return innovations compared to positive innovations of equal magnitude. In addition, increases in ex-ante volatility are associated in some subperiods with rising excess returns on longer-tierm instruments, although the slope of the yield curve and lagged excess returns generally remain significant predictors of excess returns.
\end{abstract}




\title{
Excess Returns and Risk at the Long End of the Treasury Market: An EGARCH-M Approach
}

\author{
Allan D. Brunner and David P. Simon ${ }^{1}$
}

This study models weekly excess returns of 10-year Treasury notes and 20- and 30-year (long-term) Treasury bonds over short-term Treasury bills in an exponential generalized autoregressive conditional heteroskedasticity in mean (EGARCH-M) framework. Much of the recent literature concerning risk and return at the long end of the Treasury market, including Hardouvelis (1994), Campbell and Shiller (1991) and Mankiw (1986), documents the predictive power of the slope of the yield curve for subsequent excess returns and then explores whether an omitted risk premium could explain this result. By contrast, the present paper models the risk premium as the conditional volatility of excess returns and examines whether the predictive power of the slope of the yield curve is robust to this par:icular risk premium specification. A positive relation between excess returns and the conditional volatility of excess returns could arise because fixed-income investors require higher excess returns to zompensate for greater expected volatility of excess returns, in the spirit of Engle, Lilien and Robins (1987). ${ }^{2}$

The present study also fills a gap in the term structure literature because, while many studies have modelled time-varying conditional heteroskedasticity and its relation to excess returns in the stock and foreigrt exchange markets, very few studies have examined these phenomena at the long end of the Treasury market. ${ }^{3}$ The importance of modelling heteroskedasticity is indicated by specification

1 The authors are, respectively, an economist in the Division of International Finance, Board of Governors of the Federal Reserve System and assistant professor in the Department of Fianance, Bentley College. The authors thank Tim Simin for outstanding research assistance. The views expressed are those of the authors and do not necessarily reflect the views of the Federal Reserve Board or other members of its staff. The authors are responsible for any and all errors.

2 Other possible risk premium specifications would include the covariance of excess returns with a well-dive:sified portfolio of assets.

3 Engle et al. (1987) model excess returns for Treasury bills and for long-term corporate bonds using an ARCH-M approach. Bollerslev, Engle, and Wooldridge (1988) model excess returns on bills, bonds, and stocks using a trivariate GARCH-M model. 
tests of conventional term structure models of weekly excess returns on long-term Treasury instruments from January 1968 through March 1993.

The EGARCH-M framework permits conditional volatility to change in response to excess return innovations and allows for the possibility that market participants update their forecasts of volatility differently depending on the sign of the excess holding period return innovation. In the equity market, Nelson (1991) finds that negative excess return innovations give rise to greater expected volatility increases than do positive innovations of equal magnitude. To the authors' knowledge, the possibility that a similar phenomenon exists at the long end of the Treasury market has not been examined. In addition, we permit higher interest rates to be associated with increased volatility, as assumed by the Cox, Ingersoll and Ross (1985), Brennan and Schwartz (1977) and Dotharı (1978) interest rate models. We also allow for the possibility that excess kurtosis exists in the residuals of our EGARCH-M models. While several studies have found that error term distributions of excess returns in the foreign exchange and stock markets have fat tails, no studies that we are aware of have examined whether bond market excess returns are excessively kurtotic. ${ }^{4}$

This study proceeds as follows: the first section examines preliminary regressions of excess returns of long-term Treasury instruments on the slope of the yield curve. Diagnostic tests on the residuals of these regressions indicate that they are severely misspecified. These results guide our modelling strategy, which section 2 discusses. Section 3 estimates EGARCH-M models of excess returns at the long end of the Treasury market and the final section summarizes our results.

4 See Bollerslev, Chou and Kroner (1992) for an excellent review of these studies. 


\section{Preliminary Regressions and Diagnostic Tests}

This study examines excess holding period returns on 10-year Treasury notes and 20- and 30-year Treasury bonds over one-month Treasury bills, using weekly observations from January 1968 through March 1993. The 20-year Treasury bond series, prior to 1977 , is spliced to the 30 -year Treasury bond series, which starts in 1977 when the Treasury began to auction 30-year bonds regularly. ${ }^{5}$ We use one-month Treasury bills as the risk-free instrument rather than one-week bills, because the thinness of the market for one-week bills makes these rate quotes unreliable. In addition, the one-month bill is approximately risk-free, owing to its very short duration. ${ }^{6}$ The data are from the Federal Reserve data base and represent yields at the close of business on Fridays or at the close of the previous business day if the Friday is a holiday. Treasury note and bond yields are constant maturity yields, while Treasury bill yields are coupon equivalent yields. ${ }^{7}$

In the absence of a time-varying risk premium, the expectations hypothesis states that arbitrage should cause: expected capital gains and losses on long-term instruments to offset yield differentials earned for one-week holding periods on long-term versus short-term instruments, up to a constant risk premium. As linearized version of the expectations hypothesis implies that

$$
-D_{t} \cdot\left[E_{t} R_{t+1}^{(N)}-R_{t}^{(N)}\right]=\theta+\left[R_{t}^{(N)}-r_{t}\right] / 52
$$

where $D_{t}$ is the modified duration of the long-term instrument at week $t, R_{t}$ is the yield on the

5 The T'reasury discontinued 20-year Treasury bond auctions in 1986.

6 For example, since the pricing formula for a 30 -day bill is price $=100$-(discount rate*100*30/360), a decline in rate from 7 to 6 percent results in a price increase of .08 (eight onehundredths), from 99.42 to 99.50 .

7 The U.S. Treasury calculates constant maturity yields by interpolating between yields on outstanding Treasury securities, but with most of the weight on the most recently-auctioned security in a maturity class. Constant maturity yields are used by the Treasury to indicate the yields at which they could issue par notes or bonds of a particular maturity on a given day. 
long-term instrument at week $t, r_{t}$ is the one-month bill rate at week $t, N$ is the number of years to maturity of the long-term instrument, and $\theta$ is a time-invariant risk premium. Modified duration of the long-term instrument at week $t$ is approximated by $D_{t}=\left(1-g_{t}^{2 N}\right) / 2\left(1-g_{t}\right)$, where $g_{t}=$ $1 /\left[\left(1+\left(R_{l} / 2\right)\right] .{ }^{8}\right.$ Equation (1) states that the expected capital loss (or gain) on the long-term instrument over the one-week holding period is equal to the yield pickup (or concession) earned on the long-term instrument over the short-term instrument plus a time-invariant risk premium.

Imposing rational expectations and rewriting equation (1), we express actual excess holding period returns (EXRET) as a function of a constant risk premium and a serially-uncorrelated error:

$$
\operatorname{EXRET}_{t+1}=-D_{t} \cdot\left[R_{t+1}^{(N)}-R_{t}^{(N)}\right]-\left[R_{t}^{(N)}-r_{t}\right] / 52=\theta+u_{t+1}
$$

According to the joint hypothesis of rational expectations and a constant risk premium, excisss returns should be equal to a constant plus an error term that is uncorrelated with information known at time $t$. We test a particular version of the expectations hypothesis by examining whether the slope of the yield curve predicts excess returns:

$$
\operatorname{EXRET}_{t+1}=\theta+\beta \cdot\left[R_{t}^{(N)}-r_{t}\right]+u_{t+1}
$$

If the slope of the yield curve does not forecast excess returns, the estimate of $\beta$ should no: be significantly different from zero. We begin our analysis by estimating equation (3) for both the long bond and for the 10-year note and perform a battery of specification tests on the residuals. The equations are estimated without imposing the usual constraint that the coefficients on the long- and short-term rates have equal magnitudes and opposite signs. In addition, the regressions are estimated over the full sample and for sub-samples from January 1968 through September 1979, frorn October 1979 through October 1982, and from November 1982 through March 1993.

8 This formula takes into account the semi-annual payment of coupons. 
T. The results for excess holding period returns on long-term bonds are presented in table 1. For the full sample, both long rate increases and short rate decreases are associated with higher excess returns at a 1 percent confidence level. In addition, the restriction that the coefficients are equal but of opposite signs cannot be rejected at any reasonable confidence level. This finding implies that yield curve steepenings owing to long rate increases and to short rate decreases have similar effects on subsequent excess returns. This result owes to the 1968-1979 sub-period--neither the long nor the short ratie enter the model at the five percent confidence level in either the 1979-1982 or the 1982-1993 sub-periods. Nevertheless, the portion of excess returns explained by the slope of the yield curve is minuscule, as evidenced by an $\bar{R}^{2}$ of .012 for the full sample.

By not constraining coefficients on the long and the short rates, we obtain useful information related to Froot (1989) and Campbell and Shiller (1991). These studies examine the possibility that the slope of the yield curve predicts excess returns either because long rates temporarily over-react to changes in expected future short rates or because long rates under-react to changes in actual short rate. Our results are consistent with both of these hypotheses. First, our finding that, for the whole sample period, the yield curve successfully predicts higher excess returns when long rates rise is consistent with the former hypothesis. Expected short rate increases (decreases) cause the yield curve to steepen (flatten) as long rates over-react to expected short rate increases (decreases). In the next period, long rate declines (increases) give rise to the tendency of long rates to fall (rise) and excess returns to rise (fall) following a steepening (flattening) of the yield curve. In addition, our finding that yield curve steepenings (flattenings) owing to short rate declines (increases) also are associated with statistically significant positive (negative) excess returns suggests that long-term rates may also under-react to actual short rate declines (increases) -- yield curve steepenings (flattenings) owing to short rate declines (increases) give rise to long rate declines (increases) and increased (decreased) excess returns in the following week. 
The results for the 10-year Treasury note, shown in table 2, are similar to the long bond results. For the full sample, a steepening of the yield curve, owing either to a rise in the not: rate or a fall in the one-month bill rate, is associated with an increase in the excess return on 10-year Treasury notes. The results for the note, however, are accounted for by both the 1968-1979 and the 1982-1993 sub-periods, where the coefficients on the long and the short rates are generally statistically significant and roughly equal and of opposite sign.

An important caveat to the above results is that standard inference procedures are unreliable if autocorrelation, heteroskedasticity or other sources of misspecification are present in the residuals. The bottom panels of tables 1 and 2 display the results of several diagnostic tests on the residuals from the regressions in the upper panels. The first two Lagrange multiplier (LM) tests are for misspecification of the conditional mean--regressions of residuals on 12 lags of residuals (a test for autocorrelation) and regressions of residuals on one lag of both the excess return and the squared excess return (a test for nonlinearity). The next two LM tests are for possible misspecification of the conditional variance--regressions of squared residuals on 12 lags of squared residuals (a test for $\mathrm{ARCH})$ and regressions of squared residuals on either current long- or short-term interest rates. ${ }^{9}$

Overall, these tests strongly indicate the presence of autocorrelation, nonlinearities in the mean, $\mathrm{ARCH}$, and correlation between squared excess returns and interest rates. These diagnostic tests indicate that the preliminary regressions based on equation (3) are severely misspecified, which raises the possibility that the finding that the slope of the yield curve forecasts excess returns in a simple model may be an artifact of misspecification. At minimum, the specification tests indicate that a richer model is needed to investigate excess returns at the long end of the Treasury market and guide our modelling of excess returns in the next section.

9 In each case, the LM statistic is equal to $\mathrm{NR}^{2}$, the number of regressors in the test (other than a constant) multiplied by the explained variation of the model. The statistic is distributed $\chi^{2}$ with $\mathrm{N}$ degrees of freedom. 


\section{An EGARCH-M Model of Excess Returns}

The findings of the previous section, that the residuals from regressions of excess returns on the slope of the yield curve are correlated with lagged squared excess returns and that squared residuals are highly autocorrelated, suggest that the EGARCH-M approach of Nelson (1991) may be an approprate way to model excess returns. The EGARCH-M model extends the ARCH-M model, applied to the term structure by Engle, Lilien and Robbins (1987), by allowing ex-ante excess returns volatility to differ following equal-magnitude positive and negative excess return innovations. Also, since the conditional variance of the log of excess returns is modelled as a function of lagged residuals, the EGARCH-M model does not require imposing restrictions on the coefficients of the model to erisure that the estimated variance is positive.

We specify the conditional mean of the EGARCH-M model generally as follows:

$$
\operatorname{EXRET}_{t+1}=\beta_{0}+\beta_{1} \cdot h_{t+1}+\beta_{2} \cdot \operatorname{EXRET}_{t}+\beta_{3} \cdot\left(R_{t}-r_{t}\right)+u_{t+1}
$$

where EXRET $_{t+1}$ is the excess return defined in equation (2); $h_{t+1}$ is the expected standard deviation of $u_{t+1}$, conditioned on available information at time $t ; R_{t}$ and $r_{t}$ are long and short rates, respectively; and the residual is assumed to have a generalized error distribution $--u_{t+1} \sim \operatorname{GED}\left(0, h^{2}{ }_{t+1}\right)$. According to equation (3), excess returns are driven by the expected standard deviation of excess returns, lagged excess returns, and the slope of the yield curve. We include the standard deviation rather than the variance of excess returns, because specification tests of preliminary EGARCH-M models favored the former. In addition, we constrain long and short rates to enter the excess return equation with equal and opposite signs, since estimates of unconstrained EGARCH-M models show that this restriction can not be rejected at reasonable confidence levels.

The time-varying conditional variance is modelled as follows: 


$$
\ln \left(h_{t+1}^{2}\right)=\gamma_{0}+\gamma_{1} \cdot \ln \left(h_{t}^{2}\right)+\gamma_{2} \cdot\left(\left|z_{t}\right|-f\right)+\gamma_{3} \cdot z_{t}+\gamma_{4} \cdot r_{t}
$$

where $z_{t}=u_{t} / h_{t}$, and $f=E\left|z_{t}\right|$. The model of the conditional variance in equation (5) permits the log of the variance of excess returns to be affected by its own lag, by one lag of both the absolute value and the actual value of excess return innovations and by the level of the short rate. By including both the absolute value and the actual value of lagged excess return innovations, the model allow's the ex-ante volatility of excess returns to react differently following equal- magnitude positive and negative excess return shocks. The model also allows volatility to vary with the level of short-term interest rates. We include the short rate rather than the long rate in the volatility equation because specification tests favor the short rate rather than the long rate or the spread between long and short rates. It is noted that the choice of including the conditional standard deviation rather than the conditional variance of excess returns in the excess returns equation (4) and the level of the short rate rather than the level of the long rate in the log of the conditional variance equation (5) do not qualitatively change the coefficient estimates on the other variables in the model.

Finally, the distribution of $u_{t+1}$ is assumed to be the generalized error distribution (GED):

$$
g\left(u_{t+1}\right) \propto(k+1) /\left[2^{k} \cdot \Gamma((k+1) / 2) \cdot \lambda \cdot h_{t+1}\right] \cdot \exp \left(-1 / 2 \cdot u_{t+1}^{2} / \lambda \cdot h_{t+1}^{2}\right)^{1 / k+1}
$$

where $\Gamma(\cdot)$ is the gamma function, $\left.\lambda=\left[2^{-(k+1)} \cdot \Gamma((k+1) / 2) / \Gamma(3(k+1) / 2)\right)\right]^{1 / 2}$ and $k$ measures the amount of excess kurtosis in $u_{t+1}$ relative to the normal distribution. The GED in equation (5) nests several common distributions. In particular, if $\mathrm{k}=0$, then $\mathrm{g}(\cdot)$ is distributed $\mathrm{N}\left(0, \mathrm{~h}_{\mathrm{t}+1}\right)$. In that case, $\mathrm{E}\left|\mathrm{z}_{\mathrm{t}}\right|=$ $(2 / \pi)^{1 / 2}$. If $k>0$, then the distribution of $u_{t+1}$ will have thicker tails. For example, if $k=1$, then $g(\cdot)$ is a double exponential distribution. In any case,

$$
E\left|z_{t}\right|=\Gamma(k+1) /[\Gamma((k+1) / 2) \cdot \Gamma(3(k+1) / 2)]^{1 / 2} .
$$


We use the GED rather than a standard normal distribution, since several studies have found excess kurtosis in the stock and foreign exchange markets. We find that $k$ is often significantly greater than zero for excess returns of long-term Treasury instruments.

\section{The Estimation Results}

We estimate EGARCH-M models for excess returns on long-term Treasury bonds and 10-year Treasury notes for the full sample and for subperiods from January 1968 through September 1979 and from October 1982 through March 1992. ${ }^{10}$ The models are estimated using maximum likelihood. Since the likelihood function based on equations (3) through (6) is highly nonlinear, we take several steps to ensure proper convergence. First, estimates from lower-dimensional models are used as starting values for higher-dimensional models. In addition, a wide range of starting values are used for the parameters to be estimated that are not provided by the smaller model.

Our model selection strategy is to estimate the general model shown in the previous section and then to select the optimal model based on the Akaike and Schwarz criteria. In the few cases where the criteria gave conflicting results because the Akaike selected a larger dimensional model, we choose the more parsimonious model as long as it passes the same diagnostic tests described in the previous section.

The parameter estimates for the optimal EGARCH-M models are shown in tables 3 and 4, while the results of the diagnostic tests on the residuals of these models are shown in table 5. As tables 3 and 4 indicate, the optimal EGARCH-M models of long-term bond and 10-year note excess returns fit the data much better than the standard yield curve equations do, although the $\overline{\mathrm{R}}^{2}$ (shown at the bottom of the tables) are still quite low. Moreover, as table 5 shows, the EGARCH-M models

10 W'e do not report results for the October 1979 through September 1982 period, since numerous attempts to estimate the model resulted in convergence problems, likely owing to the paucity of observations during that period. 
pass the same set of diagnostic tests examined in the previous section. ${ }^{11}$

As shown in table 3, the EGARCH-M results for weekly excess returns of long-term Treasury bonds indicate that the conditional variance of excess returns is time-varying both for the entire sample period and for each subperiod. Conditional volatility changes are highly persistent and have half-lifes of roughly 18 weeks, although the null hypothesis that conditional volatility has a unit root can easily be rejected for all time periods. ${ }^{12}$ The primary source of expected volatility changes is lagged excess return innovations; the coefficients on the absolute and the actual innovations are both statistically significantly different from zero in each time period. The finding that the coefficient on the actual innovation is significantly negative indicates that negative excess return innovation: are associated with statistically-significant greater subsequent ex-ante volatility increases than equal-magnitude positive excess return innovations. The coefficient estimates indicate that these differences are economically significant as well: For the full sample, negative excess return innovations are associated with 65 percent greater conditional volatility increases than equal-magnitude positive innovations. $^{13}$

This finding of strong asymmetric conditional volatility indicates that the same phenomenon in the equity market, referred to as the leverage effect by Black (1976), Christie (1982) and Neison

11 The diagnostic tests in table 5 assume that the residuals of the estimated EGARCH-M models are normally distributed rather than GED. However, monte carlo simulations indicate that critical values for these tests for the GED with $k=.434$ (the largest value of $k$ that we estimate) are very close to those for the normal distribution.

12 Nelson (1991) demonstrates that in EGARCH-M models with $\operatorname{ARMA}(1,1)$ representa:ions, the log of the conditional variance is stationary if the coefficient on the AR term is less than onc: Hong (1988) demonstrates that unit root tests on the variance terms of GARCH models are not asymptotically biased toward rejection, so that standard test procedures remain valid. Because $\gamma_{1}{ }^{h}=1 / 2, h$ is the half-life of a shock.

13 Based on the estimates for the entire sample, one percent positive and negative excess returns are associated with $.17\left(\gamma_{2}-\gamma_{3}\right)$ and $.28\left(\gamma_{2}+\gamma_{3}\right)$ percent increases, respectively, in the one-week ahead expected variance of excess returns. 
(1991) is not specific to that market. Our finding may not be surprising, however, in view of French, Schwert and Stambaugh (1987) and Schwert (1989), who demonstrate that financial leverage falls well short of explaining the magnitude of volatility asymmetries found in the equity market. More recently, Gallant, Rossi and Tauchen (1992) find that conditional volatility asymmetries in the equity market owe: importantly to trading volume-- asymmetries are less pronounced for large shocks when they are acisompanied by small increases in transactions volume. Unfortunately, transaction volume data for the long-term Treasury market do not exist for our sample period.

A possible explanation for conditional volatility asymmetries in the bond market is that long-term interest rate spikes during our sample period happened to presage volatile periods such as following the oil price shocks during the 1970s, the 1979-1982 period, and the period leading up to the stock market crash. A macroeconomic explanation for this phenomenon may be the strong tendency, documented by Brunner and Hess (1993), for inflation volatility to rise as the level of inflation increases. When inflation unexpectedly increases, long-term Treasury rates rise and negative excess returns are earned on long-term Treasuries. The increased volatility of inflation at higher levels of inflation may cause the ex-ante volatility of excess returns to be higher than it would be for an equivalent-magnitude unexpected inflation decrease and a commensurate positive excess return innovation.

The results also indicate that expected future volatility rises with short-term interest rate increases, a though the coefficient on the level of short rates is significant for only the full sample. This finding, also indicates that the presence of conditional volatility asymmetries in the bond market is robust to insluding the level of short rates, which contrasts with Glosten, Jagannathan and Runkle (1989), who demonstrate that conditional volatility asymmetries in the equity market disappear once interest rates are introduced into the conditional variance equation.

Our estimates also indicate the presence of a moderate degree of excess kurtosis relative to the 
normal distribution for the entire sample. However, unreported results indicate that assuming that the error term is normally distributed does not qualitatively affect the results. This is not surprising since if the conditional mean and variance equations are correctly specified, the estimates obtained under the assumption of conditional normality remain consistent under more general conditions.

The results also indicate that ex-ante volatility increases are associated with higher excess returns only in the sub-period from 1982 to 1993. Interestingly, the slope of the yield curve fails to predict excess returns only in that sub-period. Nevertheless, for the periods in which the slope of the yield curve enters the model significantly, the economic significance of the slope of the yiild curve falls somewhat when we model conditional heteroskedasticity--the estimated coefficient on the slope of the yield curve for the entire period is roughly .1 in the standard yield curve model regres:sion, shown in table 1, and .07 in the EGARCH-M model. ${ }^{14}$ Lagged excess returns are highly significiant predictors of excess returns in each time period.

The estimates for the weekly model of 10-year Treasury note excess returns (table 4) are similar to those for the long Treasury bond. As before, ex-ante volatility is time-varying in all time periods and is primarily driven by past excess return innovations. Expected future volatility increases with innovations, and negative innovations again lead to statistically and economically significant greater increases then equal-magnitude positive innovations. For the full sample period, negative innovations result in roughly a 50 percent larger volatility increase compared to positive innovations. Expected volatility is also positively correlated with the level of short-term rates in the full-sample period and for the 1968-1979 period. Ex-ante volatility changes are again highly persisterit, although once more the null hypothesis of a unit root in the variance can be rejected easily for all time periods. A moderate degree of excess kurtosis is found in the entire period, although again unreported results

14 Engle. Lilien and Robins (1987) also find that when they include the slope of the yield curve in the excess returns equation of the ARCH-M model of 6-month Treasury bill excess returns, the coefficient on the slope of the yield curve is smaller than it is in standard yield curve regressions. 
indicate that the results are not greatly changed when we assume that the error term is normally distribuled.

The results for the 10-year note also indicate that an increase in the ex-ante volatility of excess returns has a statistically significant and positive effect on actual excess returns for the entire period as well as or the 1968-1979 sub-period. The slope of the yield curve and lagged excess returns are statistically significant predictors of subsequent excess returns in each period.

\section{Conclusions}

This study finds that modeling the conditional volatility of weekly excess returns at the long end of the Treasury market from January 1968 through March 1993 is important. Our most robust finding is that the ex-ante volatility of excess returns is both statistically and economically significantly higher following a negative excess return innovation compared to an equal-magnitude positive innovation. Our EGARCH-M estimation results also provide some support for the view that the ex-ante volatility of excess returns is a risk premium that drives excess returns, although the slope of the yield curve and lagged excess returns typically continue to forecast excess returns. We also find that excess return volatility is positively correlated with the level of short-term rates, consistent with several term structure models. 


\section{References}

Black, Fischer, 1976, Studies of stock price volatility changes, Proceedings of the 1976 Mertings of the Business and Economics Statistics Section, American Statistical Association, 177-181.

Bollerslev, Tim, Ray Y. Chou and Kenneth F. Kroner, 1992, ARCH modeling in finance: A review of the theory and empirical evidence, Journal of Econometrics 52, 5-59.

Bollerslev, Tim, Robert R. Engle and Jeffrey M. Wooldridge, 1988, A capital asset pricing model of time varying covariances, Journal of Political Economy 96, 116-131.

Brennan, Michael J. and Eduardo S. Schwartz, 1977, Savings bonds, retractable bonds, and callable bonds, Journal of Financial Economics 3, 133-155.

Brunner, Allan. D. and Gregory D. Hess, 1993, Are higher levels of inflation less predictable? a state-dependent conditional heteroskedasticity approach, Journal of Business and Economic Statistics, 11, 187-97.

Campbell, John Y. and Robert J Shiller, 1991, Yield spreads and interest rate movements: a bird's eye view, Review of Economic Studies, 58, 495-514.

Christie, Andrew, 1982, The stochastic behavior of common stock variances: Value, leverage and interest rate effects, Journal of Financial Economics 10, 407-432.

Cox, J. C., J.E. Ingersoll and S.A. Ross, 1985, A theory of the term structure of interest rates, Econometrica 53, 385-407.

Dothan, L. Uri, 1978, On the term structure of interest rates, Journal of Financial Economics 6, 59-69.

Engle, Robert F., David M. Lilien and Russel R. Robins, 1987, Estimating time varying risk premia in the term structure: the ARCH-M model, Econometrica 55, 391-407.

French, Kenneth R., and G. William Schwert and Robert F. Stambaugh, 1987, Expected stock returns and volatility, Journal of Financial Economics 19, 3-30.

Froot, Kenneth A., 1989, New hope for the expectations hypothesis of the term structure of interest rates, Journal of Finance, 44, 283-306.

Gallant, A. Ronald, Peter E. Rossi and George Tauchen, 1992, Stock prices and volume, The Review of Financial Studies 5, 199-242.

Glosten, Lawrence, Ravi Jagannathan, and David E. Runkel, 1993, On the relation between the expected value and the volatility of the nominal excess return on stocks, Journal of Finance, $48,1779-1801$. 
Hardouve:lis, Gikas, 1994, The term structure spread and future changes in long and short rates in the Ci-7 countries: is there a puzzle?, Journal of Monetary Economics, 33, 255-283.

Hong, Che-Hsiung, 1988, The integrated generalized autoregressive conditional heteroskedastic model: the process, estimation and Monte Carlo experiment, unpublished manuscript, Department of
Economics, UCSD.

Mankiw, N. Gregory, 1986, The term structure of interest rates revisited, Brookings Papers on Economic Activity 1, 61-96. Nelson, Laniel B., 1991, Conditional heteroskedasticity in asset returns: a new approach, Econometrica
5!, 347-370.

Schwert (i. William, 1989, Why does stock volatility change over time?, Journal of Finance 44, 1115-1154. 
Table 1

OLS regressions of excess returns of long Treasury bonds over one-month Treasury bills on the unconstrained slope of the yield curve (1321 weekly observations from January 1968 to March 1993)

\begin{tabular}{|c|c|c|c|c|}
\hline & $1 / 68-3 / 93$ & $1 / 68-9 / 79$ & $10 / 79-9 / 82$ & $10 / 82-3 / 93$ \\
\hline & \multicolumn{4}{|c|}{ Parameter Estimates } \\
\hline constant & $\begin{array}{l}-.335 \\
(.164)\end{array}$ & $\begin{array}{l}-.141 \\
(.263)\end{array}$ & $\begin{array}{l}-3.65^{* *} \\
(1.75)\end{array}$ & $\begin{array}{l}-.321 \\
(.362)\end{array}$ \\
\hline$R_{t}$ & $\begin{array}{l}.111^{* *} \\
(.028)\end{array}$ & $\begin{array}{l}.100^{*} \\
(.045)\end{array}$ & $\begin{array}{l}.315 \\
(.162)\end{array}$ & $\begin{array}{l}.106 \\
(.057)\end{array}$ \\
\hline$r_{t}$ & $\begin{array}{l}-.087^{* *} \\
(.022)\end{array}$ & $\begin{array}{l}-.106^{* *} \\
(.028)\end{array}$ & $\begin{array}{l}-.037 \\
(.080)\end{array}$ & $\begin{array}{l}-.077 \\
(.055)\end{array}$ \\
\hline \multirow[t]{2}{*}{$\overline{\mathrm{R}}^{2}$} & .012 & .019 & .014 & .003 \\
\hline & \multicolumn{4}{|c|}{ Significance level of LM diagnostic tests } \\
\hline $\begin{array}{l}\text { Autocorrelation } \\
\text { (12 lags) }\end{array}$ & .00 & .00 & .00 & .00 \\
\hline $\begin{array}{l}\text { Nonlinear mean } \\
\quad(1 \mathrm{lag})\end{array}$ & .00 & .00 & .00 & .00 \\
\hline $\mathrm{ARCH}$ (12 lags) & .00 & .00 & .82 & .00 \\
\hline \multicolumn{5}{|l|}{$\begin{array}{l}\text { Squared residuals } \\
\text { regressed on: }\end{array}$} \\
\hline $\mathrm{R}_{\mathrm{t}}$ & .00 & .26 & .68 & .08 \\
\hline$r_{t}$ & .00 & .21 & .38 & .16 \\
\hline
\end{tabular}

Notes: $R_{t}$ is the 20-year Treasury bond rate through 1976 and the 30 -year Treasury bond rate beginning in 1977, while $r_{\mathfrak{t}}$ is the 1 -month bill rate. Nonlinear mean tests regress residuals on one own-lag and one lagged-squared residual. Standard errors are shown in parentheses, and one and two asterisks denote statistical significance at the five and one percent significance levels, res jectively. 
Table 2

OLS regressions of excess returns of 10-year Treasury notes over one-month Treasury bills on the unconstrained slope of the yield curve

(1321 weekly observations from January 1968 to March 1993)

\begin{tabular}{|c|c|c|c|c|}
\hline & $1 / 68-3 / 93$ & $1 / 68-9 / 79$ & $10 / 79-9 / 82$ & $10 / 82-3 / 93$ \\
\hline & \multicolumn{4}{|c|}{ Parameter Estimates } \\
\hline constant & $\begin{array}{l}-.228 \\
(.119)\end{array}$ & $\begin{array}{l}-.053 \\
(.219)\end{array}$ & $\begin{array}{l}-2.39 \\
(1.31)\end{array}$ & $\begin{array}{l}-.232 \\
(.237)\end{array}$ \\
\hline$R_{t}$ & $\begin{array}{l}.087^{* *} \\
(.022)\end{array}$ & $\begin{array}{l}.074 \\
(.039)\end{array}$ & $\begin{array}{l}.187 \\
(.123)\end{array}$ & $\begin{array}{l}.104^{*} \\
(.042)\end{array}$ \\
\hline$r_{t}$ & $\begin{array}{l}-.070^{* *} \\
(.018)\end{array}$ & $\begin{array}{l}-.085^{* *} \\
(.022)\end{array}$ & $\begin{array}{l}-.009 \\
(.067)\end{array}$ & $\begin{array}{l}-.088^{*} \\
(.040)\end{array}$ \\
\hline \multirow[t]{2}{*}{$\overline{\mathrm{R}^{2}}$} & .011 & .021 & .007 & .007 \\
\hline & \multicolumn{4}{|c|}{ Significance level of LM diagnostic tests } \\
\hline $\begin{array}{l}\text { Autocoirelation } \\
\text { (12 liags) }\end{array}$ & .00 & .00 & .00 & .00 \\
\hline $\begin{array}{l}\text { Nonlinerar mean } \\
\quad(1 \text { lags })\end{array}$ & .00 & .00 & .00 & .00 \\
\hline ARCH (12 lags) & .00 & .00 & .25 & .00 \\
\hline \multicolumn{5}{|l|}{$\begin{array}{l}\text { Squared residuals } \\
\text { regressed on: }\end{array}$} \\
\hline$R_{t}$ & .00 & .07 & .43 & .01 \\
\hline$r_{t}$ & .00 & .06 & .36 & .13 \\
\hline
\end{tabular}

Notes: $k_{t}$ is the 10-year Treasury note rate, while $r_{t}$ is the 1 -month bill rate. Nonlinear mean tests regress risiduals on one own-lag and one lagged-squared residual. Standard errors are shown in parentheses, and one and two asterisks denote statistical significance at the five and one percent significance levels, respectively. 
Table 3

Parameter estimates for optimal EGARCH-M models of excess returns on long-term Treasury bonds (1321 weekly observations from January 1968 to March 1993)

$$
\begin{aligned}
& \operatorname{EXRET}_{t+1}=\beta_{0}+\beta_{1} \cdot h_{t+1}+\beta_{2} \cdot E X R E T_{t}+\beta_{3} \cdot\left(R_{t}-r_{t}\right)+u_{t+1} \\
& \ln \left(h_{t+1}^{2}\right)=\gamma_{0}+\gamma_{1} \cdot \ln \left(h_{t}^{2}\right)+\gamma_{2} \cdot\left(\left|z_{t}\right|-f\right)+\gamma_{3} \cdot z_{t}+\gamma_{4} \cdot r_{t}
\end{aligned}
$$

\begin{tabular}{|c|c|c|c|c|}
\hline \multicolumn{2}{|c|}{ Parameter } & \multirow{2}{*}{$\begin{array}{c}1 / 68-3 / 93 \\
-.133 \\
(.039)\end{array}$} & \multirow{2}{*}{$\begin{array}{c}1 / 68-9 / 79 \\
-.090 \\
(.039)\end{array}$} & \multirow{2}{*}{$\begin{array}{c}10 / 82-3 / 93 \\
-.963 \\
(.529)\end{array}$} \\
\hline constant & $\left(\beta_{0}\right)$ & & & \\
\hline$h_{t+1}$ & $\left(\beta_{1}\right)$ & -- & -- & $\begin{array}{c}.789 \\
(.407)\end{array}$ \\
\hline EXRET $_{t}$ & $\left(\beta_{2}\right)$ & $\begin{array}{c}.284 \\
(.026)\end{array}$ & $\begin{array}{c}.272 \\
(.042)\end{array}$ & $\begin{array}{c}.268 \\
(.045)\end{array}$ \\
\hline$R_{t}-r_{t}$ & $\left(\beta_{3}\right)$ & $\begin{array}{c}.073 \\
(.017)\end{array}$ & $\begin{array}{c}.039 \\
(.022)\end{array}$ & -- \\
\hline constant & $\left(\gamma_{0}\right)$ & $\begin{array}{l}-.056 \\
(.022)\end{array}$ & $\begin{array}{l}-.010 \\
(.014)\end{array}$ & $\begin{array}{c}.095 \\
(.037)\end{array}$ \\
\hline $\ln \left(h^{2}\right)$ & $\left(\gamma_{1}\right)$ & $\begin{array}{c}.963 \\
(.010)\end{array}$ & $\begin{array}{c}.900 \\
(.026)\end{array}$ & $\begin{array}{c}.840 \\
(.061)\end{array}$ \\
\hline$\left|z_{t}\right|$ & $\left(\gamma_{2}\right)$ & $\begin{array}{c}.226 \\
(.038)\end{array}$ & $\begin{array}{c}.371 \\
(.063)\end{array}$ & $\begin{array}{c}.209 \\
(.055)\end{array}$ \\
\hline$z_{4}$ & $\left(\gamma_{3}\right)$ & $\begin{array}{l}-.056 \\
(.022)\end{array}$ & $\begin{array}{l}-.118 \\
(.029)\end{array}$ & $\begin{array}{l}-.064 \\
(.025)\end{array}$ \\
\hline$r_{t}$ & $\left(\gamma_{4}\right)$ & $\begin{array}{c}.009 \\
(.003)\end{array}$ & -- & -- \\
\hline Kurtosis & (k) & $\begin{array}{c}.417 \\
(.066)\end{array}$ & -- & -- \\
\hline$\overline{\mathrm{R}^{2}}$ & & .09 & .11 & .10 \\
\hline
\end{tabular}

Notes: Standard errors are in parentheses and dashes indicate variables that were excluded from the model based on Schwarz and Akaike criteria, as well as diagnostic tests. 
Table 4

Parameter estimates for optimal EGARCH-M models of excess returns on 10-year Treasury notes (1321 weekly observations from January 1968 to March 1993)

$$
\begin{aligned}
& \operatorname{EXRET}_{t+1}=\beta_{0}+\beta_{1} \cdot h_{t+1}+\beta_{2} \cdot \operatorname{EXRET}_{t}+\beta_{3} \cdot\left(R_{t}-r_{t}\right)+u_{t+1} \\
& \ln \left(h_{t+1}^{2}\right)=\gamma_{0}+\gamma_{1} \cdot \ln \left(h_{t}^{2}\right)+\gamma_{2} \cdot\left(\left|z_{t}\right|-f\right)+\gamma_{3} \cdot z_{t}+\gamma_{4} \cdot r_{t}
\end{aligned}
$$

\begin{tabular}{|c|c|c|c|c|}
\hline \multicolumn{2}{|c|}{ Farameter } & $1 / 68-3 / 93$ & $1 / 68-9 / 79$ & $10 / 82-3 / 93$ \\
\hline constant & $\left(\beta_{0}\right)$ & $\begin{array}{l}-.187 \\
(.053)\end{array}$ & $\begin{array}{l}-.263 \\
(.070)\end{array}$ & $\begin{array}{l}-.114 \\
(.098)\end{array}$ \\
\hline$h_{t+1}$ & $\left(\beta_{1}\right)$ & $\begin{array}{c}.134 \\
(.073)\end{array}$ & $\begin{array}{c}.299 \\
(.118)\end{array}$ & -- \\
\hline EXFET $_{\mathrm{t}}$ & $\left(\beta_{2}\right)$ & $\begin{array}{c}.298 \\
(.027)\end{array}$ & $\begin{array}{c}.344 \\
(.037)\end{array}$ & $\begin{array}{c}.221 \\
(.042)\end{array}$ \\
\hline$R_{t}=r_{t}$ & $\left(\beta_{3}\right)$ & $\begin{array}{c}.052 \\
(.013)\end{array}$ & $\begin{array}{c}.051 \\
(.017)\end{array}$ & $\begin{array}{c}.078 \\
(.036)\end{array}$ \\
\hline constant & $\left(\gamma_{0}\right)$ & $\begin{array}{l}-.066 \\
(.019)\end{array}$ & $\begin{array}{l}-.101 \\
(.030)\end{array}$ & $\begin{array}{l}-.010 \\
(.013)\end{array}$ \\
\hline $\ln \left(h_{t}^{2}\right)$ & $\left(\gamma_{1}\right)$ & $\begin{array}{c}.972 \\
(.008)\end{array}$ & $\begin{array}{c}.975 \\
(.013)\end{array}$ & $\begin{array}{c}.896 \\
(.063)\end{array}$ \\
\hline$|z|$ & $\left(\gamma_{2}\right)$ & $\begin{array}{c}.194 \\
(.034)\end{array}$ & $\begin{array}{c}.188 \\
(.048)\end{array}$ & $\begin{array}{c}.190 \\
(.065)\end{array}$ \\
\hline$z_{y}$ & $\left(\gamma_{3}\right)$ & $\begin{array}{l}-.041 \\
(.017)\end{array}$ & $\begin{array}{l}-.052 \\
(.021)\end{array}$ & $\begin{array}{l}-.048 \\
(.025)\end{array}$ \\
\hline$r_{t}$ & $\left(\gamma_{4}\right)$ & $\begin{array}{c}.008 \\
(.002)\end{array}$ & $\begin{array}{c}.012 \\
(.004)\end{array}$ & - \\
\hline Kurtiosis & $(\mathrm{k})$ & $\begin{array}{c}.315 \\
(.069)\end{array}$ & $\begin{array}{c}.434 \\
(.116)\end{array}$ & -- \\
\hline$\overline{\mathrm{R}} ?$ & & .10 & .14 & .12 \\
\hline
\end{tabular}

Notes: Standard errors are in parentheses and dashes indicate variables that were excluded from the model based on Schwarz and Akaike criteria, as well as diagnostic tests. 
Table 5

Significance levels of diagnostic (LM) tests

based on residuals from optimal EGARCH-M models

\begin{tabular}{|c|c|c|c|}
\hline Diagnostic Test & $1 / 68-3 / 93$ & $1 / 68-9 / 79$ & $10 / 82-3 / 93$ \\
\hline & \multicolumn{3}{|c|}{ Long-term Treasury Bonds } \\
\hline $\begin{array}{l}\text { Autocorrelation } \\
\text { (12 lags) }\end{array}$ & .55 & .49 & .14 \\
\hline $\begin{array}{l}\text { Nonlinear Mean } \\
\quad \text { (1 lag) }\end{array}$ & .41 & .51 & .46 \\
\hline $\mathrm{ARCH}$ (12 lags) & .80 & .99 & .40 \\
\hline \multicolumn{4}{|l|}{$\begin{array}{l}\text { Squared residuals } \\
\text { regressed on: }\end{array}$} \\
\hline $\mathrm{R}_{\mathrm{t}}$ & .72 & .62 & .27 \\
\hline$r_{t}$ & .76 & .37 & .20 \\
\hline & \multicolumn{3}{|c|}{ 10-year Treasury Notes } \\
\hline $\begin{array}{l}\text { Autocorrelation } \\
\text { (12 lags) }\end{array}$ & .94 & .74 & .38 \\
\hline $\begin{array}{l}\text { Nonlinear Mean } \\
\quad(1 \text { lag })\end{array}$ & .92 & .53 & .16 \\
\hline ARCH (12 lags) & .65 & .69 & .95 \\
\hline \multicolumn{4}{|l|}{$\begin{array}{l}\text { Squared residuals } \\
\text { regressed on: }\end{array}$} \\
\hline $\mathrm{R}_{\mathrm{t}}$ & .75 & .84 & .14 \\
\hline$r_{t}$ & .90 & .95 & .23 \\
\hline
\end{tabular}

Notes: In the top panel, $R_{t}$ is the 20-year Treasury bond rate through 1976 and the 30-year Treasury bond rate beginning in 1977; in the bottom panel, $R_{t}$ is the 10-year Treasury note rate. $r_{t}$ is the 1 -month bill rate. Nonlinear mean tests regress residuals on one own-lag and one lagged-squared residual. 


\section{International Finance Discussion Papers}

IFDP

Number
Titles

1995

522 Excess Returns and Risk at the Long End of the Treasury Market: An EGARCH-M Approach

521 The Money Transmission Mechanism in Mexico

520 When is Monetary Policy Effective?

519 Central Bank Independence, Inflation and Growth in Transition Economies

518 Alternative Approaches to Real Exchange Rates and Real Interest Rates: Three Up and Three Down

517 Product market competion and the impact of price undertainty on investment: some evidence from U.S. manufacturing industries

516 Block Distributed Methods for Solving Multi-country Econometric Models

515 Supply-side sources of inflation: evidence from OECD countries

514 Capital Flight from the Countries in Transition: Some Theory and Empirical Evidence

513 Bank Lending and Economic Activity in Japan: Did "Financial Factors" Contribute to the Recent Downturn?

512 Evidence on Nominal Wage Rigidity From a Panel of U.S. Manufacturing Industries

511 Do Taxes Matter for Long-Run Growth?: Harberger's Superneutrality Conjecture

Author(s)

\author{
Allan D. Brunner \\ David P. Simon \\ Martina Copelmen \\ Alejandro M. Werner \\ John Ammer \\ Allan D. Brunner \\ Prakash Loungani \\ Nathan Sheets
}

Hali J. Edison

William R. Melick

Vivek Ghosal

Prakash Loungani

Jon Faust

Ralph Tryon

Prakash Loungani

Phillip Swagel

Nathan Sheets

Allan D. Brunner

Steven B. Kamin

Vivek Ghosal

Prakash Loungani

Enrique G. Mendoza Gian Maria Milesi-Ferretti Patrick Asea

David Bowman Jon Faust

Please address requests for copies to International Finance Discussion Papers, Division of International Finance, Stop 24, Board of Governors of the Federal Reserve System, Washington, DC 20551. 


\section{International Finance Discussion Papers}

IFDP

Number
Titles

1995

509 Hysteresis in a Simple Model of Currency Substitution

508 Import Prices and the Competing Goods Effect

507 Supply-side Economics in a Global Economy

506 The Lucas Critique In Practice: Theory Without Measurement

505 Real Exchange Rate Targeting and Macroeconomic Instability

504 Inferences from Parametric and Non-Parametric Covariance Matrix Estimation Procedures

503 Exchange-Rate Based Inflation Stabilization: The Initial Real Effects of Credible Plans

502 Strategic Returns to International Diversification: An Application to the Equity Markets of Europe, Japan, and North America

501 Real Exchange Rate Movements in High Inflation Countries

500 Political Competition, Casual Relations Between Taxes and Spending, and Their Influence on Government Size: Evidence From State-Level Data

499 International Stock Price Spillovers and Market Liberalization: Evidence From Korea, Japan, and the United States

498 How Wide is the Border?
Constrained Suboptimality in Economies with Limited Communication

Saving-Investment Associations and Capital Mobility On the Evidence from Japanese Regional Data
Author(s)

Martin Uribe

Phillip Swagel

Enrique G. Mendoza

Linda L. Tesar

Neil R. Ericsson

John S. Irons

Martin Uribe

Wouter J. Den Haan Andrew T. Levin

Martin Uribe

John Ammer

Jianping Mei

John H. Rogers

Ping Wang

Diane Lim Rogers

John H. Rogers

Sang W. Kim

John H. Rogers

Charles Engle

John H. Rogers

David Bov'man

Robert Dekle 